\title{
The Impact of Interbank Offered Rate on the Exchange Rate of the Chinese Yuan Renminbi Against the Sterling Pound: Evidence from Libor and Shibor
}

\author{
Junchi Shi \\ Maoguo Wu \\ SHU-UTS SILC Business School, Shanghai University, China
}

Doi:10.19044/esj.2018.v14n22p173 URL:http://dx.doi.org/10.19044/esj.2018.v14n22p173

\begin{abstract}
United Kingdom, as the world's fifth largest economy, maintains good cooperation relation with China in the area of economy and trade. As the world's fourth largest foreign exchange trading currency, the exchange rate fluctuation of the sterling pound has an important economic impact on the world's foreign exchange market and it also has a significant impact on the trade with China.

There are many factors that influence the exchange rate. By using time series approach, this paper analyzes the impact of two main variables, Libor and Shibor, and five common economy variables, inflation rate, interest rate, balance of trade, GDP and money supply, on the change of the sterling pound exchange rate. The results of the empirical analysis show that five common factors have significant relation with exchange rate. For the two main variables, Libor has a strong correlation with the sterling pound exchange rate, but Shibor has no such relation. Meanwhile, this paper focuses on analyzing the possibility of arbitrage according to the empirical results. It was found that the model for the impact on exchange rate in this paper cannot predict future exchange rate. As a result, short-term arbitrage prediction cannot be made.
\end{abstract}

Keywords: Exchange Rate, Libor, Shibor, Time Series, Arbitrage

\section{Introduction}

For a long time, the economic and trade cooperation between China and the United Kingdom has been diversified. As a major overseas investment destination of China and the largest offshore exchange center besides Hong Kong, the exchange rate of the sterling pound and renminbi has been constantly high. So, the fluctuation of its exchange rate has a significant 
impact on Sino-British trade and the healthy development of China's economy. In addition, studying the main factors affecting the exchange rate fluctuation, exploring the relation between them, and predicting the future trend of the sterling pound exchange rate can also help enterprises to avoid foreign exchange risks effectively and enhance their competitiveness through financial derivatives. Under the condition of an open economy, interest rate and exchange rate are two important policy tools that influence the macroeconomy and maintain the stability of financial markets. Meanwhile, there is a strong interaction between interest rate and exchange rate which interact and restrict each other. Libor (London Interbank Offered Rate) and Shibor (Shanghai Interbank Offered Rate) are more objective risk-free interest rates in the market of derivatives. Besides, they are important indicators of financial liquidity. Therefore, it is imperative to study the impact of these two factors on the foreign exchange market.

This paper selects data from Libor, Shibor, and 5 common economic variables from 2006 to 2016. It also analyzes their effect on the exchange rate fluctuation of the sterling pound. The empirical results show that all 6 explanatory variables except Shibor have a significant correlation with the fluctuation of the sterling pound exchange rate.

The remaining part of this paper is organized as follows: Section 2 reviews related literature, Section 3 introduces the data, Section 4 presents the empirical analysis, Section 5 proposes policy implications, and Section 6 concludes the paper.

\section{Related Literature}

Consequently, there is a great deal of literature that investigates the linkage between exchange rate and interest rate. Only a partial selection of paper was briefly mentioned here. Sun (2010) classifies mainstream exchange rate theories by time, including "purchasing power parity (PPP)" and "covered interest parity (CIP)" in the 50's; "fixed Price: Mundell-Fleming model" and "fluctuating price: flexible price monetary model" in the late 50's to 90's; and "sticky price: sticky price-monetary model", "Portfolio balance Model", "new open macro exchange rate Model", and "micro-structure theory of foreign exchange market" in the 90's. Among them, purchasing power parity theory regards price level or inflation to be the only factor affecting exchange rate, while covered interest rate parity theory points out that interest rate is one of the important factors affecting exchange rate. In addition, the price-monetary model states that the exchange rate is influenced by the money supply. Therefore, the abovementioned literature provides the theoretical basis for selecting explanatory variables for this paper.

Previous literatures found different empirical results in regards to the relation between exchange rate and interest rate. Baxter (1994), Coughlin and Koedijk (1990), and Godlberg (2003) stated that the exchange rate is 
significantly linked with interest rate. Holffmann (2009) studied the relationship between interest rate and exchange rate in G7 countries in 19782007 using VAR model, and found the same results. Similarly, Fan (2011) conducted an ADF unit root test on interest rates and exchange rates, and concludes that the first-order difference between the exchange rate and the interest rate is stationary. Granger causality test shows that there is an obvious two-way causality. By utilizing the VAR model of exogenous variables, it concludes that there is a close relation among China's economic growth, actual spreads between the interest rates of China and America, and their exchange rate. Generally, there are three views on the linkage between exchange rate and interest rate.

1. Exchange rate and interest rate change together. Li and Luo (2006) empirically analyze the effect of the yen's long-term change on Japan's interest rates during 1997 and 2002 when yen appreciated. The empirical results show that when the real exchange rate of yen increases by $1 \%$, the real long-term interest rate in Japan is predicted to fall by $0.02 \%$. However, this shows a long-term equilibrium between the real yen exchange rate and Japan's long-term real interest rate. The Mundell Fleming model points out that there is a positive correlation between the national exchange rate and the interest rate when keeping other factors unchanged.

2. Exchange rate and interest rate change reversely. Wang (2007) took the nominal interest rate as an explanatory variable of exchange rate, with the annual deposit interest rate as the proxy variable of the nominal interest rate. Empirical analysis is based on cointegration and error correction model. The result indicates that in the short term, rising interest rate leads to increased capital inflows into the country; increases the demand for currency; and results to an appreciation of the local currency. In the long run, rising interest rates tightens monetary supply, reduces government investment, suppresses imports, promotes exports, reduces demand for foreign exchange, and appreciates the local currency.

3. There is a non-linear relation between exchange rate and interest rate. Based on the theory of interest rate parity, Zhang and Feng (2015) selected data from January 1999 to September 2011 and made use of the STR model to analyze the linkage between renminbi interest rate and exchange rate. The empirical results show that when the foreign interest rate is below the threshold level, the change in exchange rate has a significant influence on interest rate. On the other hand, when foreign interest rate is above the threshold level, the change in exchange rate has a little influence on interest rate. When foreign interest rates are near the threshold level, the effect of the exchange rate on interest rates is smoothed between two mechanisms, and the transition is fast. Therefore, it was concluded that the linkage between renminbi exchange rate and interest rate has non-linear characteristics. 
Furthermore, the study of Meese and Rogoff (1988) found an opposite result. By using unit root test and cointegration test to study the relation between interest rate and exchange rate in developed countries, they concluded that no matter the short-term, medium or long-term, the linkage between interest rate and exchange rate is not obvious. The findings of Longworth (1981) and Mishkin (1984) also supported the conclusion of Meese and Rogoff (1988).

From these research results, it can be found that previous research mainly focuses on the linkage between interest rate parity and exchange rate, and it draws different conclusions. The reasons may be due to different economies, different empirical methods, and different sample data.

\section{Empirical Analysis}

The data in this paper have eight variables and 133 months. The eight variables are sterling pound exchange rate, Libor, Shibor, inflation rate, policy interest rate, balance of trade, GDP and money supply, respectively. The 133 months refer to the data from October 2006 (when Shibor was implemented) to February 2016. The exchange rate is the explained variable. However, Shibor, Libor rate, inflation rate, interest rate, balance of trade, GDP, and money supply are explanatory variables. Descriptive statistics are summarized in Table 1.

Table 1. Descriptive Statistics

\begin{tabular}{|l|l|l|l|l|l|}
\hline Variables & Observation & Mean & Std. Dev. & Minimum & Maximum \\
\hline $\begin{array}{l}\text { Exchange Rate } \\
(\text { ER) }\end{array}$ & 113 & 11.02133 & 1.93024 & 9.05 & 15.4 \\
\hline Libor & 113 & 1.641136 & 2.035082 & 0.4603 & 5.9697 \\
\hline Shibor Rate & 113 & 2.503805 & 0.9409791 & 0.83 & 6.58 \\
\hline $\begin{array}{l}\text { Inflation } \\
\text { (Inf) }\end{array}$ & 113 & 0.0228319 & 0.0240709 & -0.1 & 0.05 \\
\hline $\begin{array}{l}\text { Interest Rate } \\
\text { (IR) }\end{array}$ & 113 & 1.60177 & 1.986179 & 0.5 & 5.75 \\
\hline $\begin{array}{l}\text { Balance of } \\
\text { trade (TB) }\end{array}$ & 113 & -3109.991 & 1052.495 & -5467 & -379 \\
\hline GDP & 113 & 133702.7 & 21549.1 & 117105 & 157070 \\
\hline $\begin{array}{l}\text { Money Supply } \\
\text { (MS) }\end{array}$ & 113 & 1662.013 & 206.0672 & 1469.42 & 2010.5 \\
\hline
\end{tabular}

Table 1 lists the mean, standard deviation, and minimum and maximum of the variables. There are 8 independent variables, and the number of variables for each independent variable is 113 . Among the 8 variables, the data of Shibor and Libor are gathered from the East Money Data Center and the data of the British GDP. Inflation and balance of trade are gathered from the British National Bureau of Statistics; the data of money supply are gathered from the International Monetary Fund; and the data on policy interest rate are gathered from the Bank of England. 
In order to find whether the data are stationary and to avoid the occurrence of "spurious regression", ADF test was first performed on the eight variables. The results show that some variables have unit roots, while others do not. So, this paper further studies the stationarity through Augmented Dickey-Fuller test and carries out ADF test on all variables. The results are shown in Table 2.

Table 2. ADF Test

\begin{tabular}{|l|l|l|l|l|}
\hline Variables & T-value & P-value & Stationarity & Conversion \\
\hline ER & -1.768 & 0.3963 & not stationary & DLER \\
\hline Libor & -1.533 & 0.5174 & not stationary & DLibor \\
\hline Shibor & -3.993 & 0.0014 & stationary & \\
\hline INF & -4.628 & 0.0001 & stationary & \\
\hline IR & -1.580 & 0.4938 & not stationary & DIR \\
\hline TB & -7.281 & 0.0000 & stationary & \\
\hline GDP & -1.671 & 0.4459 & not stationary & DLGDP \\
\hline MS & -1.805 & 0.3777 & not stationary & DLMS \\
\hline
\end{tabular}

For the non-stationary variables, this paper first takes the natural logarithm of non-percentage variables into consideration. For example, it makes ER LER, and then tests its stationarity. If variables are still not stationary, the first-order difference to variables is performed again, which is DLER. This is done until the variable becomes stationary. For Libor and IR, the first-order difference is directly performed to make variables stationary.

The stationarity of the transformed variables is tested again. The test results show that DLER, DLibor, DIR, DLGDP, and DLMS are all stationary. The Augmented Dickey-Fuller test finds the same results.

Furthermore, the autocorrelation of eight variables is examined to see if there is white noise in the variable. If white noise exists, then the variables have autocorrelation. The test results are shown in Table 3.

Table 3. Autocorrelation Test

\begin{tabular}{|l|l|l|l|}
\hline Variables & Q-value & P-value & White Noise \\
\hline DLER & $(\mathrm{Q})=33.07$ & $\mathrm{P}=0.7729$ & No \\
\hline DLIBOR & $(\mathrm{Q})=298.7$ & $\mathrm{P}=0.0027$ & Yes \\
\hline SHIBOR & $(\mathrm{Q})=298.7$ & $\mathrm{P}=0.0000$ & Yes \\
\hline INF & $(\mathrm{Q})=243.4$ & $\mathrm{P}=0.0000$ & Yes \\
\hline DIR & $(\mathrm{Q})=120.7$ & $\mathrm{P}=0.0000$ & Yes \\
\hline TB & $(\mathrm{Q})=74.28$ & $\mathrm{P}=0.0008$ & Yes \\
\hline DLGDP & $(\mathrm{Q})=181.6$ & $\mathrm{P}=0.0000$ & Yes \\
\hline DLMS & $(\mathrm{Q})=12.88$ & $\mathrm{P}=1.0000$ & No \\
\hline
\end{tabular}

As can be seen in Table 3, there is no autocorrelation for variable DLER and DIMS, and other variables have autocorrelation.

Granger causality test shows that DLibor and DIR are the Granger causes of the variable DIER. However, this shows that explanatory variables results to the change of the explained variable. 
Table 4. Granger Causality Test

\begin{tabular}{|c|c|c|c|}
\hline Variables & $\begin{array}{l}\text { Coefficient } \\
\text { (Std. Err) }\end{array}$ & $\mathbf{T}$ & $\mathbf{P}>|\mathbf{T}|$ \\
\hline \multicolumn{4}{|l|}{ DLER } \\
\hline L1 & $\begin{array}{l}.0095043 \\
.1051668\end{array}$ & 0.09 & 0.928 \\
\hline L2 & $\begin{array}{l}.2572606 \\
.1174706 \\
\end{array}$ & 2.29 & 0.045 \\
\hline \multicolumn{4}{|l|}{ Dlibor } \\
\hline L1 & $\begin{array}{l}-.0483143 \\
.039508\end{array}$ & -1.22 & 0.224 \\
\hline L2 & $\begin{array}{l}-.0734582 \\
.0374787\end{array}$ & -1.96 & 0.041 \\
\hline \multicolumn{4}{|l|}{ Shibor } \\
\hline L1 & $\begin{array}{l}.0049927 \\
.0045592 \\
\end{array}$ & 1.10 & 0.276 \\
\hline L2 & $\begin{array}{l}.0051403 \\
.004481 \\
\end{array}$ & -1.15 & 0.254 \\
\hline \multicolumn{4}{|l|}{ INF } \\
\hline L1 & $\begin{array}{l}-.2426481 \\
.1514631 \\
\end{array}$ & -1.60 & 0.113 \\
\hline L2 & $\begin{array}{l}.179242 \\
.1653075\end{array}$ & 1.08 & 0.281 \\
\hline \multicolumn{4}{|l|}{ DIR } \\
\hline L1 & $\begin{array}{l}.0819832 \\
.0417487\end{array}$ & 1.96 & 0.053 \\
\hline L2 & $\begin{array}{l}.1029887 \\
.0502384 \\
\end{array}$ & 2.05 & 0.034 \\
\hline \multicolumn{4}{|l|}{ TB } \\
\hline L1 & $\begin{array}{l}-7.88 \mathrm{e}-08 \\
2.97 \mathrm{e}-06 \\
\end{array}$ & -0.03 & 0.979 \\
\hline L2 & $\begin{array}{l}3.44 \mathrm{e}-06 \\
2.78 \mathrm{e}-06\end{array}$ & 1.24 & 0.219 \\
\hline \multicolumn{4}{|l|}{ DLGDP } \\
\hline L1 & $\begin{array}{l}-.0134449 \\
.2481239\end{array}$ & -0.05 & 0.957 \\
\hline L2 & $\begin{array}{l}.251976 \\
.2446372\end{array}$ & -1.03 & 0.097 \\
\hline \multicolumn{4}{|l|}{ DLMS } \\
\hline L1 & $\begin{array}{l}.1048007 \\
.1150262\end{array}$ & 0.91 & 0.365 \\
\hline L2 & $\begin{array}{l}-.1142390 \\
.113108\end{array}$ & -1.01 & 0.081 \\
\hline
\end{tabular}

It is common that time series may be associated with each other at different times and the explained variable might be affected by other factors besides the listed explanatory variables. In order to prevent the invalidity of the parameter estimator, the misleading results of significance test, and the failure of model prediction caused by serial correlation, this paper focuses on 
the serial correlation test and performs a simple regression on the explained variable. The regression equation is as follows:

$$
\begin{aligned}
& d l E R={ }_{0}+{ }_{1} d \text { Libor }+{ }_{2} \operatorname{Shibor}(2)+{ }_{3} \operatorname{Inf}(2)+{ }_{4} d I R \\
& +{ }_{5} T B(2)+{ }_{6} d l G D P+{ }_{7} d l M S+
\end{aligned}
$$

This paper uses Durbin-Watson Statistics and Breusch-Godfrey LM to test the serial correlation. The results are as follows:

Table 5. Durbin-Watson Test

\begin{tabular}{|l|l|l|l|}
\hline \multicolumn{4}{|l|}{ Durbin-Watson d-statistic $(17,109)=2.125233$} \\
\hline Durbin-Watson Test & chi2 & df & Prob > chi2 \\
\hline Lags(p) & 4.628 & 1 & 0.0315 \\
\hline 1 & \multicolumn{3}{|l|}{} \\
\hline H0: There is no serial correlation
\end{tabular}

Table 6. Breusch-Godfrey LM Test

\begin{tabular}{|l|l|l|l|}
\hline \multicolumn{4}{|l|}{ Breusch-Godfrey LM Test } \\
\hline Lags(p) & chi2 & df & Prob > chi2 \\
\hline 1 & 5.275 & 1 & 0.0216 \\
\hline H0: There is no serial correlation & \\
\hline
\end{tabular}

From Table 5 and Table 6, it can be seen that serial correlation exists. Since serial correlation has serious consequences for OLS regression, this paper applies Cochrane-Orcutt $\mathrm{AR}(1)$ regression to correct the effect of serial correlation. Six regression results are obtained by adding explanatory variables one by one. The regression results are summarized in Table 7.

Table 7. Regression Results and Robustness Test

\begin{tabular}{|l|l|l|l|}
\hline DLER & Regression 5 & Regression 6 & Regression 7 \\
\hline \multirow{3}{*}{ DLIBOR } & -.0629095 & -.0612582 & -.0594551 \\
& .030628 & .0307385 & .0309776 \\
& $* *$ & $* *$ & $* *$ \\
\hline \multirow{3}{*}{ L2.SHIBOR } & -.0048257 & -.00504477 & -.00522661 \\
& .0024621 & .0025608 & .0026397 \\
& $* *$ & $* *$ & $* *$ \\
\hline \multirow{3}{*}{ L1.INF } & -.1653913 & -.20304757 & -.2070035 \\
& .1002372 & .1035957 & .103605 \\
& $*$ & $* *$ & $* *$ \\
\hline \multirow{2}{*}{ DIR } & .1122212 & .1109268 & .1081519 \\
& .0347139 & .0350007 & .0353643 \\
\hline \multirow{3}{*}{ L2.TB } & $* * *$ & $* * *$ & $* * *$ \\
\hline \multirow{2}{*}{ DLGDP } & $2.66 \mathrm{e}-06$ & $2.24 \mathrm{e}-06$ & $2.20 \mathrm{e}-06$ \\
& $2.29 \mathrm{e}-06$ & $2.39 \mathrm{e}-06$ & $2.39 \mathrm{e}-06$ \\
\hline \multirow{2}{*}{ DLMS } & $*$ & $* *$ & $* *$ \\
\hline & & -.3617643 & -.0 .4517577 \\
& & .2191183 & .2303711 \\
\hline & & $* *$ & -.2798327 \\
\hline & & & .1057665 \\
\hline
\end{tabular}


NOTE: ***,**, * indicates that the variable is significant at $1 \%, 5 \%, 10 \%$ significance level, respectively.

Table 7 shows the regression results and significance obtained by stepwise regression of variables. The results show that:

1. Regardless of several regressions, the policy interest rate still has a significant impact on the exchange rate of the sterling pound at a $1 \%$ significance level.

2. Within the $10 \%$ significance interval, all explanatory variables have a significant effect on the explained variable.

3 . When the seventh regression was done, all explanatory variables are controlled at the $5 \%$ significance level.

Choosing to add too many lag items may increase the error of the prediction. On the other hand, adding too few lag items may lose relevant information, experience, knowledge, and theories. Usually, there are three methods of calculations, Sbic, AIC and HQIC, which can be used to detect the best lag periods. The results are shown in Table 8 below.

Table 8. Selection of Lag Period

\begin{tabular}{|c|c|c|c|c|c|c|c|c|}
\hline \multicolumn{9}{|c|}{ Selection-Order Criteria } \\
\hline \multicolumn{6}{|c|}{ Sample: $12-111$} & \multicolumn{3}{|c|}{ Observed Value $=100$} \\
\hline $\begin{array}{l}\text { Lag } \\
\text { Period }\end{array}$ & $\mathrm{LL}$ & LR & Df & $\mathrm{P}$ & FPF & AIC & HQIC & SBIC \\
\hline 0 & 482.425 & & & & $\begin{array}{l}2.9 \mathrm{e}- \\
12\end{array}$ & -9.5285 & -9.46523 & -9.37218 \\
\hline 1 & 605.922 & 247 & 36 & 0.000 & $\begin{array}{l}5.1 \mathrm{e}- \\
13 \\
\end{array}$ & -11.2784 & $\begin{array}{l} \\
10.8356 *\end{array}$ & $\begin{array}{l}-1843 * \\
10.184\end{array}$ \\
\hline 2 & 648.021 & 84.198 & 36 & 0.000 & $\begin{array}{l}4.5 \mathrm{e}- \\
13^{*}\end{array}$ & - $11.4004 *$ & -10.578 & -9.3684 \\
\hline 3 & 672.08 & 48.118 & 36 & 0.085 & $\begin{array}{l}5.9 \mathrm{e}- \\
13\end{array}$ & -11.1616 & -9.95964 & -8.19171 \\
\hline 4 & 700.97 & 57.78 & 36 & 0.012 & $\begin{array}{l}7.0 \mathrm{e}- \\
13 \\
\end{array}$ & -11.0194 & -9.43787 & -7.11165 \\
\hline 5 & 723.251 & 44.561 & 36 & 0.155 & $\begin{array}{l}9.9 \mathrm{e}- \\
13\end{array}$ & -10.745 & -8.78391 & -5.8994 \\
\hline 6 & 757.731 & 68.96 & 36 & 0.001 & $\begin{array}{l}1.1 \mathrm{e}- \\
12 \\
\end{array}$ & -10.7146 & -8.37394 & -4.93114 \\
\hline 7 & 785.835 & 56.209 & 36 & 0.017 & $\begin{array}{l}1.5 \mathrm{e}- \\
12\end{array}$ & -10.5567 & -7.83646 & -3.83537 \\
\hline 8 & 815.837 & 60.002 & 36 & 0.007 & $\begin{array}{l}2.1 \mathrm{e}- \\
12 \\
\end{array}$ & -10.4367 & -7.33692 & -2.77753 \\
\hline 9 & 861.93 & 92.187 & 36 & 0.000 & $\begin{array}{l}2.2 \mathrm{e}- \\
12\end{array}$ & -10.6386 & -7.15922 & -2.04154 \\
\hline 10 & 905.409 & $86.957^{*}$ & 36 & 0.000 & $\begin{array}{l}2.7 \mathrm{e}- \\
12 \\
\end{array}$ & -10.7882 & -6.92922 & -1.25325 \\
\hline \multicolumn{9}{|c|}{ Endogenous Variables: DLER Shibor Dlibor DINF DIR DLGDP } \\
\hline Exog & Varia & : _cons & & & & & & \\
\hline
\end{tabular}


As can be seen from Table 8, the results are different among three methods. This is because VAR is used in this paper, and AIC is the most suitable method for VAR. The sample size in this paper is relatively small. Therefore, two lags are selected in this paper.

VAR is generally used to predict the time series that are associated with each other and that are used to analyze the dynamic impact of different types of random disturbances on system variables. This paper uses VAR to test the endogeneity of variables. The results are shown in Table 9.

Table 9. VAR Regression Results

\begin{tabular}{|c|c|c|c|c|}
\hline Lag Period & Coefficient & (Std. Err) & $\mathrm{Z}$ & $\mathrm{P}>|\mathrm{z}|$ \\
\hline & \multicolumn{4}{|l|}{ DLIBOR } \\
\hline L1. & -.0085319 & .0457149 & -0.19 & 0.852 \\
\hline \multirow[t]{2}{*}{ L2. } & -.0248461 & .0368028 & -0.68 & 0.500 \\
\hline & \multicolumn{4}{|l|}{ SHIBOR } \\
\hline L1. & -.0016968 & .0046419 & -0.37 & 0.715 \\
\hline \multirow[t]{2}{*}{ L2. } & .0003291 & .0046045 & 0.07 & 0.943 \\
\hline & \multicolumn{4}{|l|}{ INF } \\
\hline L1. & -.1156285 & .2026799 & -0.57 & 0.568 \\
\hline \multirow[t]{2}{*}{ L2. } & .2163488 & .2375743 & 0.91 & 0.362 \\
\hline & \multicolumn{4}{|l|}{ DIR } \\
\hline L1. & .0486831 & .0470078 & 1.04 & 0.300 \\
\hline \multirow[t]{2}{*}{ L2. } & -.0081651 & .0488721 & -0.17 & 0.867 \\
\hline & \multicolumn{4}{|l|}{$\mathrm{TB}$} \\
\hline L1. & $3.93 \mathrm{e}-06$ & $2.86 \mathrm{e}-06$ & 1.37 & 0.169 \\
\hline \multirow[t]{2}{*}{ L2. } & $-2.08 \mathrm{e}-06$ & $2.83 \mathrm{e}-06$ & -0.73 & 0.463 \\
\hline & \multicolumn{4}{|l|}{ DLGDP } \\
\hline L1. & -.0699373 & .2558775 & -0.27 & 0.785 \\
\hline \multirow[t]{2}{*}{ L2. } & -.0073192 & .2503424 & -0.03 & 0.977 \\
\hline & \multicolumn{4}{|l|}{ DLMS } \\
\hline L1. & .0742248 & .1158218 & 0.64 & 0.522 \\
\hline L2. & -.0233127 & .1152318 & -0.20 & 0.840 \\
\hline
\end{tabular}

After VAR test, this paper analyses the VAR model. Since the VAR model is a non-theoretical model, this paper adopts the impulse response function (IRF), which is used to analyze the change of endogenous variables' current and future value when subjected to a standard deviation shock from the residual error. It can intuitively describe the dynamic interaction effects between variables.

It can be seen from Figure 1 that DLIBOR has an impulse impact and an immediate effect on DLER. 


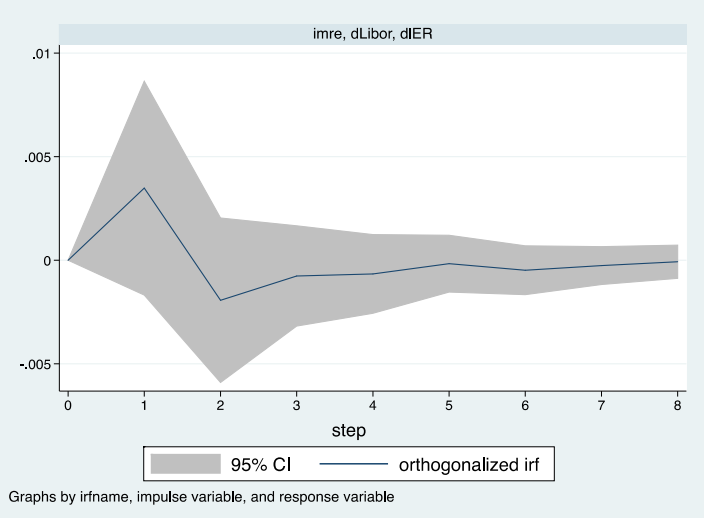

Figure 1. The Impulse Response of DLER to DLIBOR

It can be seen from Figure 2 that there is an impulse response of DIR to DLER, and DIR has an immediate effect on DLER.

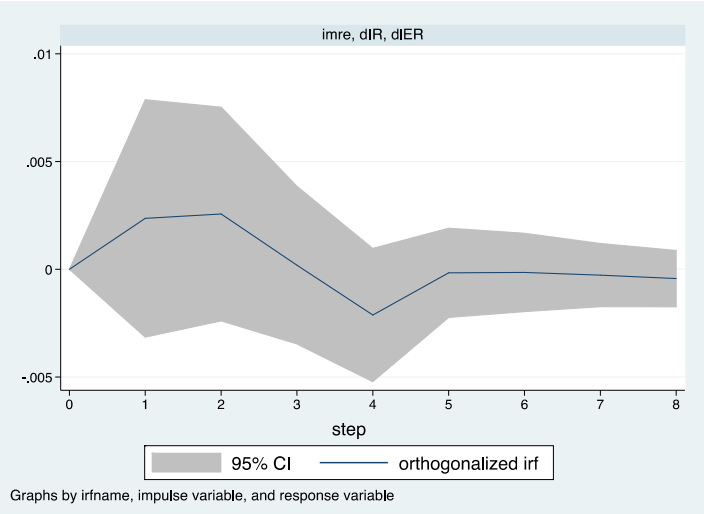

Figure 2. The Impulse Response of DIR to DLER

It can be seen from Figure 3 that there is an impulse response of DLGDP to DLER, and DLGDP has an immediate effect on DLER.

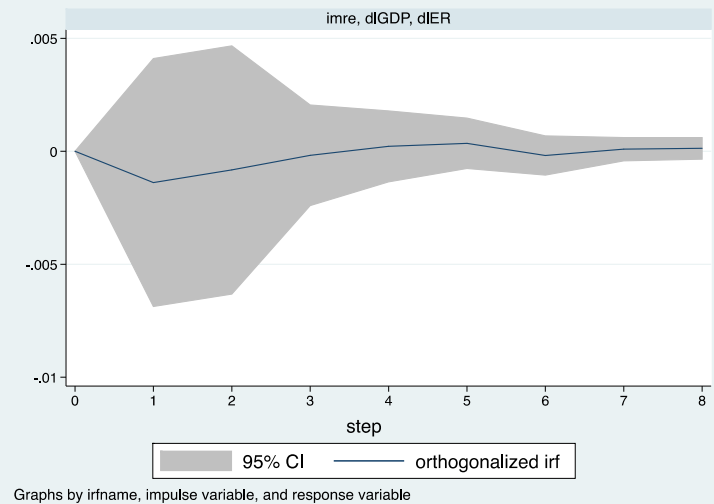

Figure 3. The Impulse Response of DLGDP to DLER 
It can be seen from Figure 4 that there is an impulse response of DLMS to DLER, and DLMS has an immediate effect on DLER.

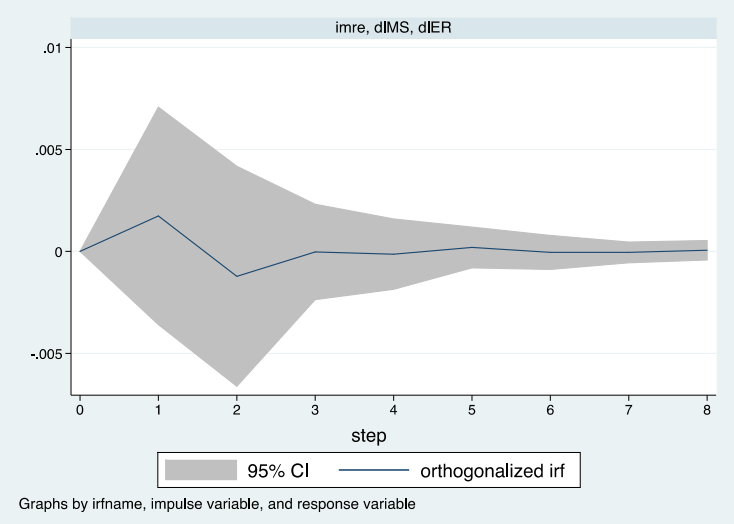

Figure 4. The Impulse Response of DLMS to DLER

Finally, this paper adopts variance decomposition, which concludes that $41 \%$ of the DLIBOR variance is related to the DLER variance, $26 \%$ of the DIR variance is related to DLER variance, and other correlation coefficients are relatively small. The decomposition results are shown in Table 10. Table 10. Variance Decomposition Results

\begin{tabular}{|l|l|l|l|l|l|l|}
\hline Gr & Regressor & Factor & (Std. Err) & P>|t| & Std.Coef. & Shapley \%R2 \\
\hline 1 & DLIBOR & -.0273838 & .0288208 & 0.048 & -.0576712 & 40.7616 \\
\hline 2 & L2.SHIBOR & .0072953 & .0187947 & 0.065 & 0.0419 & 1.5736 \\
\hline 3 & L2.INF & -.0548943 & .0794552 & 0.052 & -0.0702 & 2.1735 \\
\hline 4 & DIR & $.0098218 * *$ & .0037569 & 0.001 & 0.013 & 26.6961 \\
\hline 5 & TB & .0071912 & .0002486 & 0.041 & 0.00216 & 9.60912 \\
\hline 6 & DLGDP & $-.1076196 *$ & .0573505 & 0.012 & -0.0257 & 12.0375 \\
\hline 7 & DLMS & $.0027368 * *$ & .0012998 & 0.004 & 0.0207 & 7.25 \\
\hline- & Intercept & .4256467 & .6935886 & 0.054 & & \\
\hline Number of variables: 113 \\
\hline
\end{tabular}

\section{Arbitrage}

Through the above empirical analysis, it can be concluded that sterling pound exchange rate is significantly affected by Libor, inflation rate, interest rate, balance of trade, GDP, and money supply. Therefore, this paper attempts to predict the future exchange rate of the sterling pound through this formula, which provides the basis for arbitrage.

This paper establishes the arbitrage regression equation:

$d l E R(+1)={ }_{0}+{ }_{1} d$ Libor $(+1)+{ }_{2}$ Shibor $+{ }_{3} I n f+{ }_{4} d I R(+1)+{ }_{5} T B+{ }_{6} d l G D P(+1)+{ }_{7} d l M S(+1)$ 
The regression results are shown in Table 11:

Table 11. One Lag Regression

\begin{tabular}{|l|l|l|l|l|ll|}
\hline F. DLER & Factor & (Std. Err) & $\mathrm{T}$ & $\mathrm{P}>|\mathrm{t}|$ & {$[95 \%$ Conf. Interval] } \\
\hline DLIBOR & & & & & & \\
\hline F1 & -.0594551 & .0309776 & -1.92 & 0.058 & -.1209062 & .001996 \\
\hline SHIBOR & -.0004555 & .0026397 & -0.17 & 0.863 & -.005692 & .0047809 \\
\hline INF & -.0470035 & .103605 & -0.45 & 0.651 & -.2525279 & .1585209 \\
\hline DIR & & & & & & \\
\hline F1 & .1081519 & .0353643 & 3.06 & 0.003 & .0379986 & .1783052 \\
\hline TB & $2.20 \mathrm{e}-06$ & $2.39 \mathrm{e}-06$ & 0.92 & 0.360 & $-2.54 \mathrm{e}-06$ & $6.93 \mathrm{e}-06$ \\
\hline DLGDP & & & & & & \\
\hline F1 & -.1525101 & .2303711 & -0.66 & 0.509 & -.6095044 & .3044841 \\
\hline DLMS & & & & & & \\
\hline F1 & -.0798327 & .1057665 & -0.75 & 0.452 & -.2896449 & .1299795 \\
\hline cons & .0068362 & .0100442 & 0.68 & 0.498 & -.0130888 & .0267613 \\
\hline
\end{tabular}

It can be seen from Table 11 that the lag period explanatory variables are not significant except the interest rate. This, therefore, means that the model cannot be used to make predictions based on the regression equation. This is because arbitrage is based on short-term change. While facing different market and different prices, the behavior of buying low and selling high will be quickly corrected by the market and lead prices to return to equilibrium. However, the impact of the explanatory variables discussed in this paper on the explained variables is in long term. As a result, this paper cannot help to make arbitrage transactions.

\section{Policy Implications}

From the empirical results, it can be seen that the exchange rate of the sterling pound is greatly affected by Libor. After the economic crisis in 2008, the frustration of the banking industry led to a sharp drop in the value of the sterling pound. As a lesson, China needs to adjust its economic structure to promote economic diversification and avoid the occurrence of an economic crash of the entire country when an accidental event strikes a particular pillar industry.

From the econometric specification, it can be seen that balance of trade has an important impact on the exchange rate. The increase in balance of trade can lead to an increase in the demand of the sterling pound in the market, which will further increase the exchange rate of the sterling pound. On the contrary, a decrease in balance of trade can lead to a decrease in the exchange rate of the sterling pound. Due to the Brexit, the deficit between UK and European Union expanded to 8.1 billion pounds, which also led to the continued depreciation of the sterling pound. In contrast, China has a large 
trade surplus. However, the main source of China's trade surplus comes from low-cost goods and demographic dividends. Therefore, in order to maintain China's trade surplus status, China has to transform low-cost goods into hightech products.

The market benchmark interest rate can reflect the capital cost and supply and demand situation, and its changes will inevitably cause the change of others according to interest rate in the interest rate system. Since Shibor was officially implemented across the national banks from January 1st, 2007, the process of China's marketization of interest rate has accelerated significantly. The introduction of Shibor can provide pricing benchmarks for short-term bonds, currency market derivatives, and other products. However, the operation of Shibor to establish pricing benchmarks seldom happens in people's daily life. Therefore, at this stage, the central bank should further improve Shibor's benchmark status, issue related support policies, accelerate the formation of Shibor's benchmark status, improve the Shibor-based market interest rate system, and further leverage Shibor's pricing benchmarks on floating-rate bonds and derivatives. Furthermore, it gradually promotes the market reform of deposit and lending rates. Finally, it helps to cultivate financial institution's pricing mechanism based on Shibor, and also enhance financial institution's independent pricing power.

\section{Conclusion}

Based on the theoretical model of exchange rate and interest rate, this paper studies the factors affecting the exchange rate through data from UK from October 2006 to February 2016. The following conclusions can be drawn. First, by variance decomposition, it can be seen that there is a negative correlation between Libor and the sterling pound exchange rate. However, the interpretation of the exchange rate is as high as $40 \%$. This shows that when Libor rises, the sterling pound will rise because the rise in Libor can lead to the increase in banks' borrowing costs and the banking business will shrink. As the amount of credit reduces, the amount of renminbi that enters the foreign exchange market and the supply of renminbi is also reduced. As a result, renminbi appreciates so that the exchange rate of the sterling pound falls. Hence, Shibor and the exchange rate of the sterling pound are positively correlated and have no significant impact on the exchange rate. Besides, the linkage between the two was not strong and the degree of explanation was only $1 \%$. This result may be due to the low marketization of interest rates in China and the low flexibility of exchange rate. Second, through the impulse response, it can be seen that when Libor is impacted, it has a greater impact on the exchange rate in the first and second periods. Basically, it stabilizes at the third period. The policy interest rate has the greatest impact on the exchange rate in the fourth period, and tends to be stationary in the fifth period. 
GDP in the previous periods has an impact on the exchange rate, and the impact is found to decrease from the third period. The largest impact of the money supply on the exchange rate is in the second period, and it attenuates in the remaining periods. In general, the relation between exchange rate and interest rate is basically negative. Third, China needs to speed up interest rate marketization because it can be seen from the empirical results that the impact of interest rates on the exchange rate of China is very small. The insufficient degree of interest rate marketization will obstruct the effective transmission of monetary policy and reduce the pricing capability of the risky assets of financial institutions.

\section{References:}

1. Fan, Y. (2011). An Empirical Study on the Interaction between RMB Exchange Rate and Interest Rate.

2. Luo, Z. \& Li, N. (2006). An Empirical Analysis of Real Exchange Rate of Yan and Real Interest Rate.

3. Sun, Y. (2010). A Summary of Empirical Studies on Factors Affecting Exchange Rate in Chronological Order.

4. Wang, Z. (2007). An Empirical Study on the Relationship between Interest Rate and Exchange Rate in the Process of Interest Rate Marketization in China.

5. Zhang, Q. \& Feng, F. (2015). An Empirical Analysis of Based on Smooth Transition Model for The Nonlinear Adjustment of RMB Exchange Rate and Interest Rate. 1: 26-34.

6. Zhao, T. \& Li, C. (2010). The Dynamic Relationship between the RMB Exchange Rate and Interest Rate: An Empirical Study Based on the VAR-GARCH Model. 